\title{
A colorless sequence of structural analysis in Seto Dharatee
}

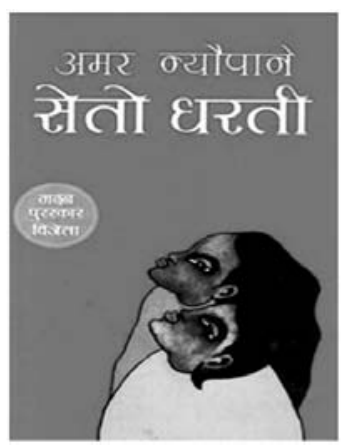

Bipana Koirala

Nyaupane, A. (2012) Seto Dharatee. Fineprint: Bishalbazaar, Kathmandu.Nepali Fiction. Fineprints Books, Nepal. Pages 373. ISBN 978-9937-8563-4-8

This review is a brief interpretation of structural symmetry of Amar Nyaupane's Seto Dharatee; a fiction; exploring the underlying units of which the text is built and aims to explore the notion of narrative grammar using the theoretical insights from the Tzvetan Todorov's structural framework. The narrative grammar is analysed by the actions like 'to seek', 'to find' and 'to lose'. This study contributes to compare the structural analysis of other novels' with this novel written in the same era. This also depicts how the repetition of same grammar and same formula constitute the entire text. Through the review is of a Nepali novel, readers of the Journal of NELTA may benefit from the structural, linguistic and interpretative analysis of the novel.

Seto Dharatee is a Madan Puraskar winning novel; a very popular Nepali fiction, by Amar Nyaupane.The fiction is interpreted by the theoretical insights from structuralism, particularly within the notion of schema of propositions as usedby Tzvetan Todorov (as cited in Tyson, 2006). According to this framework, the narrative grammar of the text is interpreted i.e. the structure of text by the pattern of reoccurring events (verb), attributes (adjectives) and Their relation to the particular character (noun). The repetition of the same grammar in the fiction is analysed. Based upon this, all the actions of the novel can be reduced to three verbs; to seek, to find and to lose.

If we suppose $\mathrm{X}$ as a particular character and $\mathrm{Y}$ as a wish, desire, object or emotion then the above action can be represented as:

$\mathrm{X}$ seeks $\mathrm{Y}$, finds $\mathrm{Y}$ and loses $\mathrm{Y}$.

Or

X lacks $Y$ but does not find it.

With reference to these actions, I, therefore, interpret the fiction "Seto Dharatee" considering the main character of the fiction Tara.

The novel begins with a narrative of the main character, Tara, who is tired with the struggles of her life; her desire is to forget all the misfortunes that dragged her down. 
She seeks to forget her past (seek), realizes that she does not remember how she was born (find) and again realizes her experiences are still with her (lose). This beginning leads the text to a point where Tara seeks basic literacy to write her name, Govinda (her childhood friend) teaches her some alphabet; she departs from Govinda (source of education). The day when Tara's mother denies her to play, she wants to play with her friends, she goes to play but she is called by her mother at home as the guests bringing marriage proposal for Tara were in.

The seek-find-lose structure leads the text to Tara's wedding at the age of 7 years. Tara wants to enjoy the ceremony (seek), she gets to eat delicious food and wear new dresses (find) but she ultimately feels sleepy and tired in her marriage ceremony (lose). When she reaches her in-laws' home, she seeks her parents, she gets to return to her own parents for four years after a day, her husband dies after two years and she again needs to go to her in-laws.

She also wants her parents to visit her when she is with her in-laws, her parents come but she cannot see them due to a cultural reason. She again wishes to return to her own home, she goes to her home after a year but she is again forced to stay with her pregnant mother in law. Tara wants to be free from cultural boundaries and attend the program to meet the young Sadhu, she is allowed to attend it but she cannot follow him as Pavitra (Tara's friend who is also a child widow like Tara) did.

Being bound in social and religious practices, Tara cannot get right to be remarried or attain the sexuality of her life. That is why she seeks to satisfy her desire. Yamuna's (Tara's friend who shares every romantic moments of her life with Tara) marital story and her relationship with her husband satisfy Tara's desire to be loved. This can be illustrated by the following part of the text:

Yamuna: Does not the story of my sexual life hurt your emotions?

Tara: If it hurts me, why would I listen to you? In fact, it gives me an equal pleasure as you have experienced. ( $p .178)$

But when Yamuna departs she realizes that her sexual life is never successful without a man in her life.

Tara has an intense desire to utilize the natural right of motherhood, she feeds her breast to her younger brother (their mother die leaving a nine months old younger brother behind) and tries to experience the feeling of being a mother, her brother also sucks it as if it were his mother's breast. Tara's emotions get hurt when her brother starts crying as the mammary glands cannot produce milk for him. In this moment Tara loses her feeling of motherhood (p.160). This incident can also be illustrated from the perspective of the child; Tara's brother. He seeks his mother and cries all 
day after Tara pulls him away from a dog whose breast he was sucking. After sucking his sister breast, he gets silent as if he had got her dead mother back again but when the breast cannot provide him milk, he cries again.

The seek-find-lose structure is applied on several more incidents on Tara's life. After Tara leaves her home to move to a holy place, Devghat, she wants a man to love her in her life. She find Swami ji (He is the head and controller of the Ashrams; a holy place to stay) with whom she falls in love with and even Swamiji falls in love with her. But the ethics of the religion does not allow him to marry due to which her love fails. Tara, whose hair is shaved frequently for being a child widow, wants to have her hair long, she grows her hair and combs it well but Swamiji does not allow her. She goes for a pilgrimage in India and shaves her head.

Tara always wants to meet her childhood friend Pavitra (she had gone to India with young sadhu and no one knows anything else about her). Pavitra comes in Devghat (changing her name to Gangeswori) as an intelligent woman and shares her life journey with Tara. Tara feels as if she is a betrayer in Devghat (as Pavitra had once worked as a prostitute) and she loses her friend that she really wanted back.

Tara wants the colors back to her life (a widow is not allowed wearing colorful clothes) and she decides to live a life of a saint. She accomplishes it but her whiteness (symbol of widow in Traditional Hindu society) only turns to yellow (symbol of saint); not her desires. Tara had always been in love with Govinda (her childhood friend with whom she once played/acted a marriage in her childhood) and saw him in her dreams. She wanted to be with him. When she is at the age of seventy seven, he also comes to stay in the old age home of Devghat. But she cannot start a relationship with him as both of them are very old.

\section{The novel ends with Tara's narration:}

"I prayed and lived to satisfy God in my entire life. But I guess God never realised my sorrow, he never satisfied me. Maybe that's why I am crying". (p. 353)

This narration also explains how the character sought God (hope and satisfaction) and her attempts failed to find God.

This is the structural interpretation on seek-find-lose basis considering the main character of the text, Tara. It can also be applied upon other characters as well like:

a) Tara's mother wants to have a son, she gives birth to a son (elder than Tara), and he dies at the age of three.

b) Govinda wants a happy life with his family in city, he marries to a literate city girl (though he had a wife already in the village) to stay in city but he is left at elderly home in Devghat during his old age. 
c) Tara's stepmother (married at the age of 11 with Tara's Father after demise of his wife) loves Tara's younger brother(of same age to that of his stepmother) as her husband, she gets to spend her time with him when other member of the family are away but he shifts away after his marriage.

However, it is not applied on Pavitra's life in this text. Pavitra always wanted a colorful life (not like a life of child widow). She escapes out from her society to become a freely independent woman and she accomplishes it as well being a mother of a daughter.

The seek-lose-find has the possibility of redemption of traditional quest. Traditional quest is based on seek and find grammar. It can be explained by following interpretation:

1) Attribute: Tara (analogous to protagonist) is unsuccessful and unsatisfied with her experiences.

2) Action : She seeks or tries to make her life meaningful through various attempts.

3) Attribute: She has at least found out the meaning of life at the end.

The seek-lose-find grammar in Seto Dharatee makes it sound as a pessimistic novel as there is always a "lack" from the beginning to end of the Novel. But the significance of this structure is that it reflects the reality of human life which is usually lack of something that we desire. Thus, this also opposes the traditional quest.

The repetition of seek-find-lose grammar on the text gives the repetitive moves to the events of the fiction. The enormously complex structural system is provided with this functional rule, which the reader operates unconsciously. The significance of lose-find-seek rule in Seto Dharatee is to compare the novel's structural system with those of other novels written at the same time. We do not necessarily interpret the structures for the incidents but the analysis provides some kind of formulaic move to the literature. We can depict a sequence in any kind of literature, movies, paintings, or plays if once we get the idea of structures. The interpretation of Seek-Lose-Find in Seto Dhaatee can help the bulks of history, literature or the events of everyday life reduce to a rule that governs the entire system.

\section{References:}

Tyson, L. (2006) Critical theory today; a user friendly guide. Routledge: London. 